\title{
WestVirginiaUniversity
}

THE RESEARCH REPOSITORY @ WVU

West Virginia Agricultural and Forestry Experiment

Davis College of Agriculture, Natural Resources

Station Bulletins

And Design

$1-1-1965$

\section{The effect of soil compaction on nitrogen transformations in the soil}

Frank D. Whisler

Carl F. Engle

N.W. Baughman

Follow this and additional works at: https://researchrepository.wvu.edu/ wv_agricultural_and_forestry_experiment_station_bulletins

\section{Digital Commons Citation}

Whisler, Frank D.; Engle, Carl F.; and Baughman, N. W., "The effect of soil compaction on nitrogen transformations in the soil" (1965). West Virginia Agricultural and Forestry Experiment Station Bulletins. 516T.

https://researchrepository.wvu.edu/wv_agricultural_and_forestry_experiment_station_bulletins/661 @ WVU. It has been accepted for inclusion in West Virginia Agricultural and Forestry Experiment Station Bulletins by an authorized administrator of

The Research Repository @ WVU. For more information, please contact ian.harmon@mail.wvu.edu. 


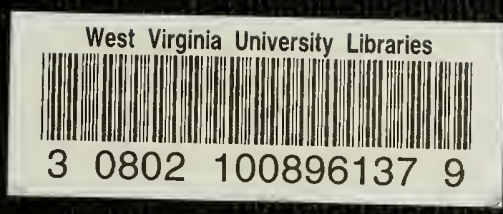


Digitized by the Internet Archive in 2010 with funding from

Lyrasis Members and Sloan Foundation

http://www.archive.org/details/effectofsoilcomp516whis 
Bulletin 516T November 1965

WEST VIRGINIA UNIVERSITY

AGRICULTURAL EXPERIMENT STATION

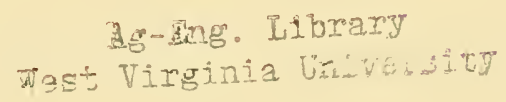

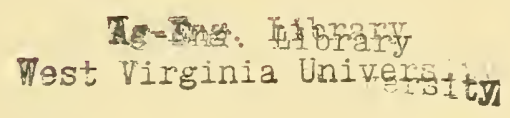

The Effect of Soil Compaction On Nitrogen Transformations

In the Soil 


\section{THE AUTHORS}

F. D. Whisler, at the time of this study, was a Research Assistant in Agronomy; C. F. Engle is Assistant Agronomist; and N. M. Baughman, former Agronomist, is now at Makerere University, Kampala, Uganda, East Africa.

WeSt VIRGINA UNIVERSITY

Agricultural Experiment Station

College of Agriculture and Forestry

A. H. VanLandingham, Director

MORGANTOWN 


\section{The Effect of Soil Compaction On Nitrogen Transformations In the Soil}

\section{F. D. Whisler, C. F. Engle, and N. M. Baughman}

Soil compaction results in increased soil density with consequent changes in the air space and moisture relationships in the root zone. As the soil density is increased the pore volume is lowered and the proportion of fine pores increased. This indirectly reduces plant growth by (a) lowered oxygen tension in the root zone, (b) increased soil moisture tension in the root zone, (c) mechanical impedance to root elongation, and (d) possible reduction in availability of mineral nutrients.

Soil compaction is of particular concern in relation to soil nitrogen transformations. Breazeale and McGeorge (4) found that nitrification stopped and denitrification took place on puddled alkaline-calcareous soils. Bower et al. (3) stated that nitrogen availability seemed to be related to the extent to which tillage preparations of a corn seedbed aerates the soil. Swanson and Jacobson (17) found that nitrate production and its uptake by corn was greater in cultivated than noncultivated soils or soils in which weeds were controlled by 2, 4-dichlorophenoxyacetic acid $(2,4-D)$. Surface crusting of the soil in the two latter treatments reduced nitrification. Smith and Cook (14) reported that compaction reduced nitrification, but that forced aeration increased nitrification somewhat. Mitsui et al. (12) and Soubies et al. (16) reported that losses of ammonia from urea increased with alkalinity, soil compaction, and waterlogged conditions. Arnold (1) found that soils approaching saturation with water may rapidly release large amounts of available nitrogen as nitrous oxide, indicating the influence of oxygen deficiency in nitrous oxide production.

The study reported here was conducted to evaluate the influence of soil compaction on nitrogen transformations in the soil as affected by (a) soil type, (b) source of applied nitrogen, and (c) rate of nitrogen application. 


\section{Experimental Materials and Methods}

Three soils were used in this study - Monongahela sandy loam, Wharton clay loam, and Pope sandy loam. Some chemical and physical characteristics of the soils are given in Table 1. Organic matter was determined by the potassium dichromate wet combustion method (19). Particle size and aggregate analyses were determined by a modification of the Bouyoucos hydrometer method (2). $\mathrm{pH}$ was determined in a 1:1 soil:water suspension.

Bulk samples of the soils were air-dried and screened through a 1/4inch mesh sieve. Nitrogen fertilizer material, urea or ammonium sulfate, was added to bulk samples of the soils to give $0,25,50$, and $75 \mathrm{ppm} \mathrm{N}$. Duplicate samples were then weighed for compaction to give bulk densities of $1.3,1.5$, and $1.7 \mathrm{~g} / \mathrm{cc}$, respectively, when compacted in 3-inch cylinders.

Each soil sample was spread on a sheet of paper, moistened with a fine spray of water and thoroughly mixed, subdivided, and each subsample compacted into the cylinder. The volume of water necessary to moisten the soil was determined by prior calibration.

After compaction, the cylinders of soil were saturated with distilled water under vacuum. The saturated soils were then placed on a tension table, set at $50 \mathrm{~cm}$ of water tension. When equilibrium was reached, after 24 hours, the soils were placed in a constant temperature incubator that contained a free water surface. Total porosity, $50-\mathrm{cm}$ porosity, and moisture content were determined from weighings. It was found that the soils varied in air-filled porosity even though compacted to the same bulk density. The water used to saturate the soil cores and that which was drained from the soil at $50-\mathrm{cm}$ tension was tested for its ammonium and nitrate nitrogen content. The amounts found were insignificant.

The Monongahela soil settled at a bulk density of $1.3 \mathrm{~g} / \mathrm{cc}$ following saturation. The actual bulk density was found to be $1.4 \mathrm{~g} / \mathrm{cc}$. The greatest bulk density that could be obtained with the Pope soil was 1.6 g/cc.

Samples treated with ammonium sulfate and urea were incubated at $30^{\circ} \mathrm{C}$ for two and four weeks, respectively. Uncompacted soils of the same weight were placed in $600-\mathrm{ml}$ beakers and incubated as checks. Bulk densities of the uncompacted soils were determined following incubation. Moisture contents were maintained by periodically bringing the samples to their original weight with distilled water.

Ammonium and nitrate nitrogen were determined, following incubation, by Richardson's modification of the method of Olsen (13). Moisture contents were determined gravimetrically. Available nitrogen, 


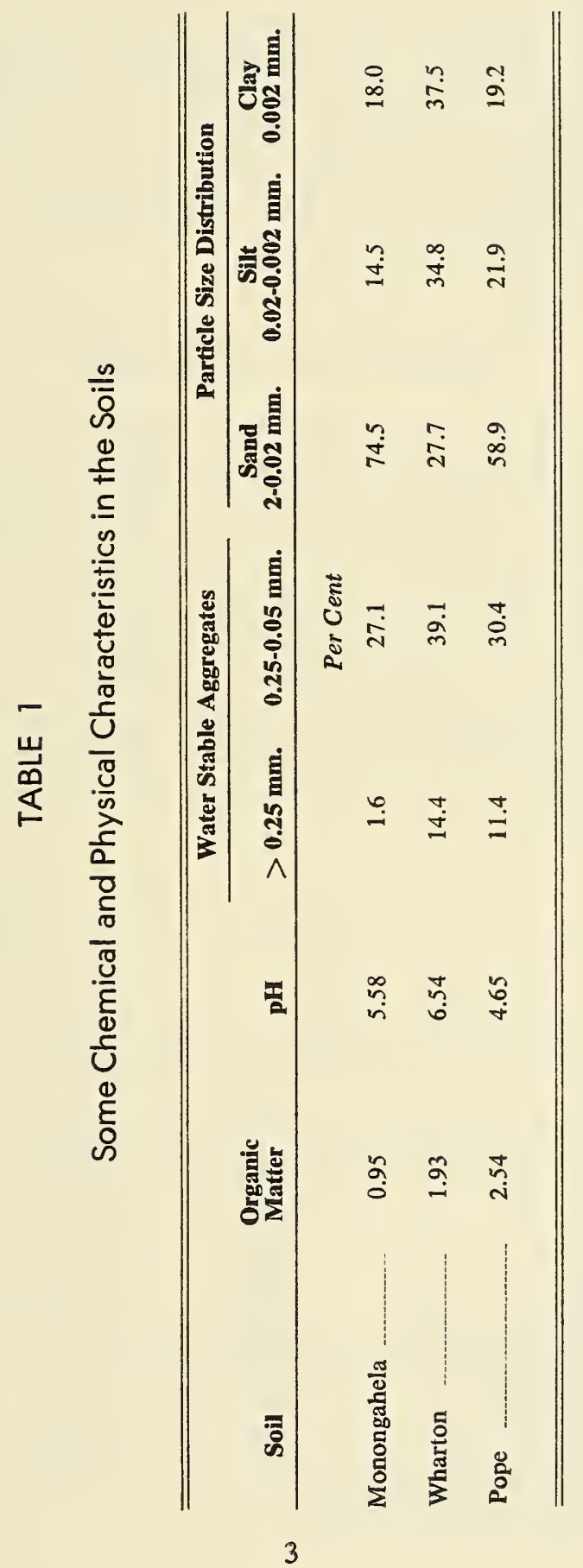


apparently mineralized from organic matter in the soil, was calculated by subtracting the amounts of ammonium and nitrate nitrogen originally present and that added as urea or ammonium sulfate from the total ammonium and nitrate nitrogen found at the end of the incubation period. This is referred to as native- $\mathrm{N}$ mineralized in the tables. The values may not be absolute because of possible losses of gases to the atmosphere.

The data were statistically analyzed to test the various treatments for significance. The " $F$ " test as given by Snedecor (15) was applied to each of the nitrogen transformations studied.

\section{Results and Discussion}

A summary of the results of statistical analysis of the data is given in Table 2. All main treatment effects were significant at the 1 per cent level for ammonium, nitrate, and native mineralized nitrogen produced during incubation. With the exception of soil type by source for all transformations and source by rate for native mineralized nitrogen, all interactions were significant at the 1 per cent level.

Table 3 shows the transformation of nitrogen in ammonium sulfatetreated soils after two weeks incubation. Most of the ammonium sulfate added to the Monongahela soil was rapidly transformed regardless of bulk density. In the Wharton soil ammonium nitrogen accumulated at a bulk density of 1.7. The Pope soil showed an accumulation of ammonium nitrogen at all bulk densities.

\section{TABLE 2}

Statistical Analysis and F Values

\begin{tabular}{|c|c|c|c|c|}
\hline Treatment & D. F. & $\mathbf{N H}_{4} \cdot \mathbf{N}$ & $\mathrm{NO}_{3}-\mathbf{N}$ & $\begin{array}{c}\text { Native-N } \\
\text { Mineralized }\end{array}$ \\
\hline Soil Type & 2 & $643.9 * *$ & $837.1 * *$ & $34.6 * *$ \\
\hline $\mathrm{N}$-Source & 1 & $506.8 * *$ & $864.1 * *$ & $55.5 * *$ \\
\hline $\mathrm{N}$-Rate & 3 & $18.7 * *$ & $304.4 * *$ & $19.7 * *$ \\
\hline Compaction & 3 & $58.4 * *$ & $1104.3 * *$ & $246.9 * *$ \\
\hline Soil Type by Source & 2 & $3.1 \mathrm{NS}$ & $2.1 \mathrm{NS}$ & $1.7 \mathrm{NS}$ \\
\hline Soil Type by Rate & 6 & $18.6 * *$ & $34.1 * *$ & $5.2 * *$ \\
\hline Soil Type by Compaction & 6 & $41.0 * *$ & $171.9 * *$ & $17.9 * *$ \\
\hline $\mathrm{N}$-Source by Rate & 3 & $74.5 * *$ & $54.5 * *$ & $2.7 \mathrm{NS}$ \\
\hline N-Source by Compaction & 3 & $8.0 * *$ & $163.1 * *$ & $18.6 * *$ \\
\hline $\mathrm{N}$-Rate by Compaction - & 9 & $2.6 * *$ & $11.8 * *$ & $3.8 * *$ \\
\hline
\end{tabular}

**-Significant at .01 confidence level

NS-Not significant at .05 confidence level 


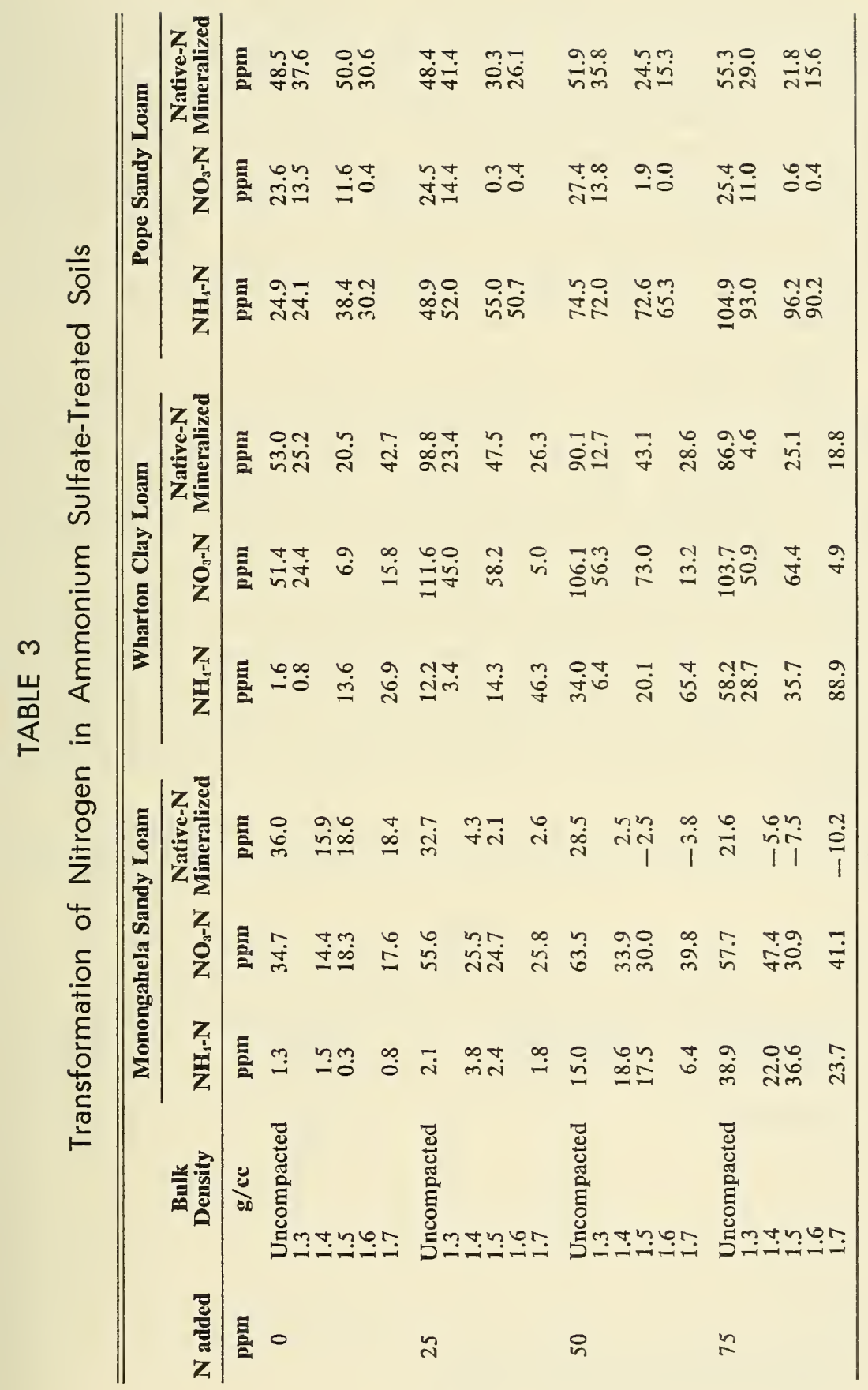


There was an accumulation of nitrate nitrogen in the Monongahela soil at all levels of compaction. The greatest difference occurred between the uncompacted and compacted samples. In the Wharton soil, nitrate nitrogen accumulated at bulk densities of 1.3 and 1.5, but there was little accumulation at bulk density of 1.7. The Pope soil showed the same general trends, but with lower accumulations of nitrate nitrogen at the lowest bulk densities and almost no production of nitrates at bulk densities 1.5 and 1.6. The low amounts of nitrate nitrogen found in the Pope soil may have been due to a combination of the low $\mathrm{pH}$ of the soil $(\mathrm{pH} 4.65)$ and to a small aeration porosity. It averaged 5.3 and 3.4 per cent aeration porosity at bulk densities of 1.5 and 1.6, respectively (Table 4 ).

Table 5 shows the transformation of nitrogen in urea-treated soils incubated for four weeks. In the Monongahela soil ammonium nitrogen did not accumulate regardless of the treatment. In the Wharton soil ammonium nitrogen did not accumulate in the uncompacted samples and at a bulk density of 1.3. There was some accumulation of ammonium nitrogen at a bulk density of 1.5, especially at the lower rates of urea application. Appreciable ammonium nitrogen accumulated at a bulk density of 1.7 and generally increased with the rate of urea application. In the Pope soil, ammonium nitrogen accumulated at all levels of compaction and nitrogen application. There was a general trend in all soils toward higher accumulation with higher rate of nitrogen application. The increase in ammonium nitrogen was related to a decrease in nitrate nitrogen.

The nitrate nitrogen content of the urea-treated soils generally was less as soil compaction increased. In the Monongahela soil no differences

\section{TABLE 4}

Per Cent Aeration Porosity of the Soils*

\begin{tabular}{lccc}
\hline $\begin{array}{c}\text { Bulk Density } \\
\text { g/ce }\end{array}$ & $\begin{array}{c}\text { Monongahela } \\
\text { Sandy Loam }\end{array}$ & $\begin{array}{c}\text { Wharton } \\
\text { Clay Loam }\end{array}$ & $\begin{array}{c}\text { Pope } \\
\text { Sandy Loam }\end{array}$ \\
\hline Uncompacted & 30.8 & 32.6 & 34.7 \\
1.3 & 28.8 & 18.9 & 23.1 \\
1.4 & 26.5 & & 5.3 \\
1.5 & & 6.7 & 3.4 \\
1.6 & 18.1 & 6.8 & \\
1.7 & & & \\
\hline
\end{tabular}

*Values are the average of four samples. 


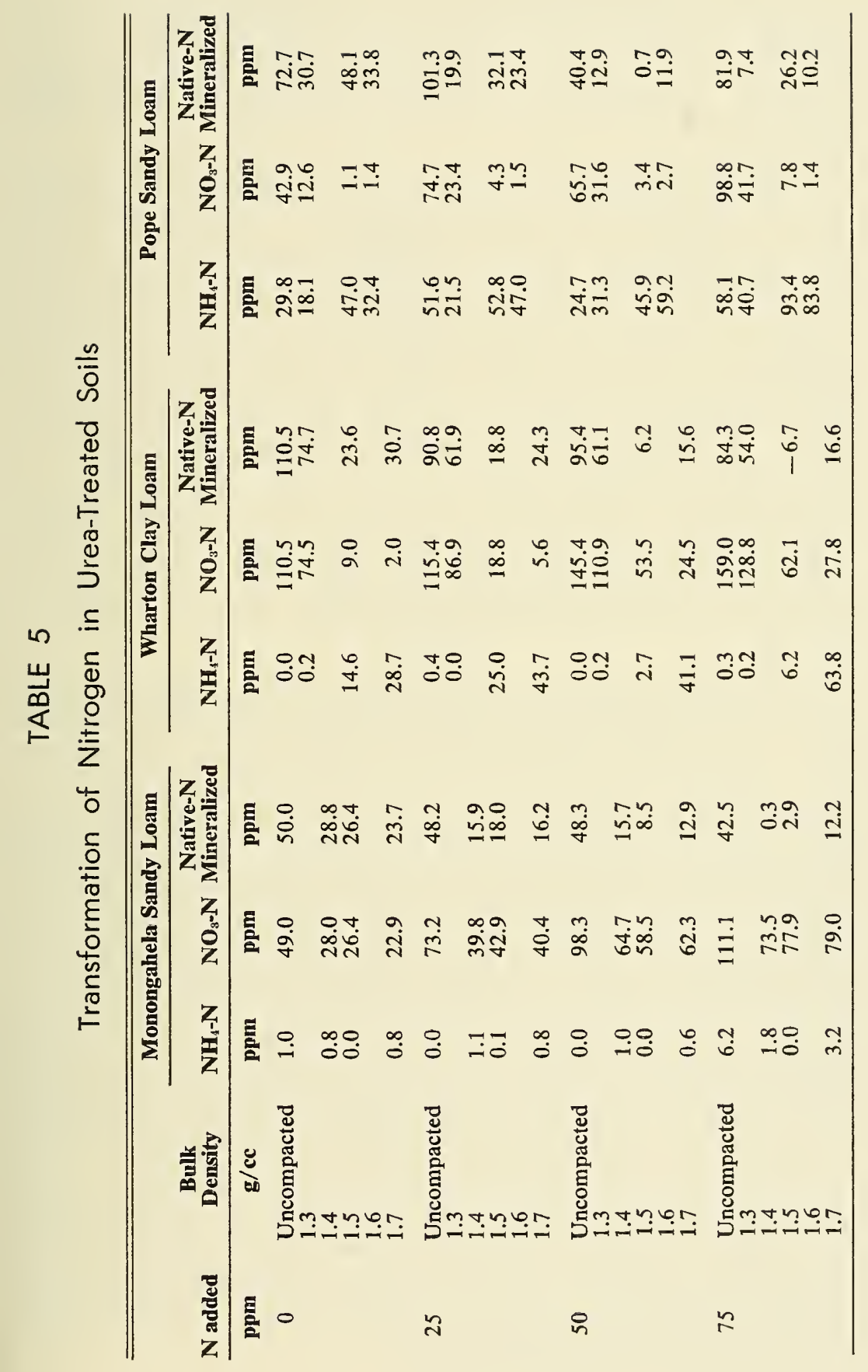


were detectable among compaction levels, but the uncompacted soil was higher in nitrate at all levels of urea. In the Wharton soil distinct differences occurred in nitrate accumulation among compaction rates. Little nitrate accumulated at the higher bulk densities. In the Pope soil nitrates accumulated only in the uncompacted soil and at a bulk density of 1.3 .

Differences in the amount of native nitrogen mineralized in the three soils are shown in Tables 3 and 5. These differences represent ammonium and nitrate mineralized from the soil organic matter in excess of that added and originally present in the soil. Negative values sometimes occur and appear to indicate that nitrogen losses and/or conversions exceeded the gains from mineralization. The data show consistent and appreciable differences in the amount of native nitrogen mineralized among uncompacted and compacted samples for the three soils, two ritrogen sources, and four nitrogen rates. This points to the conclusion that the differences are largely due to loss of nitrogen gases to the atmosphere with even a modest increase in bulk density. The data are not consistent with increased levels of bulk density and/or rates of nitrogen application. This may be due to the interaction between nitrogen rates and compaction levels which statistically was found to be highly significantly different (Table 2).

The literature lists numerous conditions under which soils lose nitrogen to the atmosphere as gases of various types. The conditions which are pertinent to this study are $\mathrm{pH}(6,8,10,11,18)$, reduced aeration through compaction and saturation with water $(12,16)$, and source and rate of nitrogen fertilization $(9,12,18)$. The relative loss of gases from the three soils in this study, based on these studies but not taking into account the aforementioned interaction, would be in order of Pope $>$ Wharton $>$ Monongahela. The Monongahela soil probably lost the least because it had good aeration porosity at all rates of compaction (Table 4) which should have resulted in most of the ammonium nitrogen being converted to nitrates. However, with a $\mathrm{pH}$ of 5.58 some nitrogen could have been lost through reduction of nitrates to nitric or nitrous oxide gases (7), and possibly even to free nitrogen gas (5). The Pope soil probably lost the most of the above gases because of its low aeration porosity, especially at the higher bulk densities, and very strongly acid $\mathrm{pH}$. Also, its much greater organic matter content (Table 1) would provide more nitrogen to be mineralized and lost as one of the partially oxidized gases. The nearly neutral Wharton soil probably lost gas to the atmosphere only under anaerobic conditions. With sufficient aeration ammonium would be converted to nitrates; however, a small amount may have been lost as ammonia gas (11). 


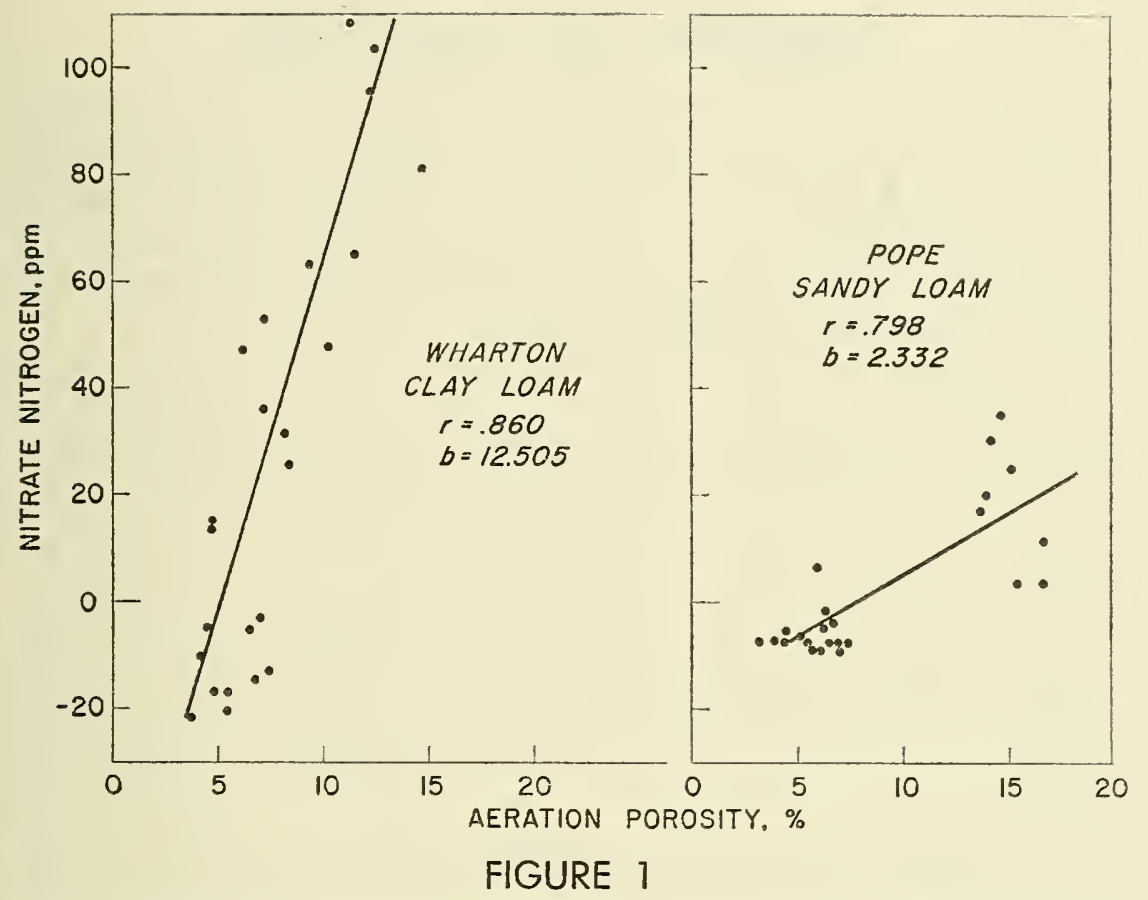

THE REGRESSION OF NITRATE NITROGEN ON AERATION FOR TWO SOILS TREATED WITH UREA

Much of the literature points to the importance of aeration in the nitrification process. It seemed advisable, therefore, to analyze statistically the data to find the correlation and regression of the amount of nitrate nitrogen produced on the per cent aeration. This was done for each nitrogen source and each soil type. The correlation coefficients were tested as outlined in Snedecor (15). Correlation coefficients were significant only for the urea-treated Wharton and Pope soils. Figure 1 shows the regression of nitrate nitrogen on aeration for these two soils. In each case the correlation coefficients were highly significant. The lack of correlation when ammonium sulfate was used may indicate a compaction $\times$ aeration $\times$ nitrification interaction. 


\section{SUMMARY AND CONCLUSIONS}

The effects of soil compaction on nitrogen transformation were studied for three soil types. Ammonium sulfate and urea were used as sources of nitrogen at rates of $0,25,50$, and $75 \mathrm{ppm}$ nitrogen. The soils were incubated at $30^{\circ} \mathrm{C}$ for two weeks where ammonium sulfate was used and four weeks where urea was used. After incubation the soils were tested for ammonium and nitrate nitrogen.

Analysis of variance of the data showed highly significant differences among soil types, nitrogen sources, nitrogen rates and compaction levels in the amounts of various forms of nitrogen produced during incubation.

Correlation of soil aeration porosity with nitrate production was found to be highly significant for only two soil types and one nitrogen source.

Increasing the soil compaction increased the amount of ammonium nitrogen recovered after incubation but decreased the amount of nitrate nitrogen recovered. Even slight compaction of the three soils resulted in a noticeable reduction in the amounts of nitrates produced and nitrogen mineralized from organic matter during incubation. This was true regardless of the source or rate of nitrogen applied or the $\mathrm{pH}$ of the soil.

The results of the study suggest a compaction $X$ aeration $\times$ nitrification interaction. 


\section{LITERATURE CITED}

1. Arnold, P. W. 1954. Losses of Nitrous Oxide from Soil. J. Soil Sci. 5:116-126.

2. Bouyoucos, G. J. 1936. Directions for Making Mechanical Analyses of Soils by the Hydrometer Method. Soil Sci. 42:225-230.

3. Bower, C. A., G. M. Browning, and R. A. Norton. 1944. Comparative Effects of Plowing and Other Methods of Seedbed Preparation on Nutrient Element Deficiencies in Corn. Soil Sci. Soc. Am. Proc. 9:142-146.

4. Breazeale, J. F. and W. T. McGeorge. 1937. Studies on Soil Structure: Some Nitrogen Transformations in Puddled Soils. Ariz. Agr. Exp. Sta. Tech. Bull. 69.

5. Broadbent, F. E. and B. F. Stojanovic. 1952. The Effect of Partial Pressure of Oxygen on Some Nitrogen Transformations. Soil Sci. Soc. Am. Proc. 16:359-363.

6. Chao, T. T. and W. Kroontje. 1960. Ammonia Adsorption Phenomena in Soil. Proc. Intern. Congr. Soil Sci. Seventh Madison. 2:517-522.

7. Chao, T. T. and W. Kroontje. 1963. Inorganic Nitrogen Oxidations in Relation to Associated Changes in Free Energy. Soil Sci. Soc. Am. Proc. 27:44-47.

8. Chao, T. T. and W. Kroontje. 1964. Relationships between Ammonia Volatilization, Ammonia Concentration, and Water Evaporation. Soil Sci. Soc. Am. Proc. 28:393-395.

9. du Plessis, M. C. F. and W. Kroontje. 1964. The Relationship between $\mathrm{pH}$ and Ammonia Equilibria in Soil. Soil Sci. Soc. Am. Proc. 28:751-754.

10. Ernst, J. W. and H. F. Massey. 1960. The Effects of Several Factors on Volatilization of Ammonia Formed from Urea in the Soil. Soil Sci. Soc. Am. Proc. 24:87-90.

11. Kresge, C. B. and D. P. Satchell. 1960. Gaseous Loss of Ammonia from Nitrogen Fertilizers Applied to Soil. Agron. J. 52:104-107.

12. Mitsui, S., K. Ozaki, and M. Moriyama. The Volatilization of Ammonia Transformed from Urea. 1954. J. of the Sci. of Soil and Manure 25:17-19. Japan. (Chem. Abs. 48:11720. 1954).

13. Piper, C. S. 1942. Soil and Plant Analysis. The Univ. of Adelaide. Adelaide.

14. Smith, F. W. and R. L. Cook. 1946. The Effect of Soil Aeration, Moisture, and Compaction on Nitrification and Oxidation and the Growth of Sugar Beets Following Corn and Legumes in Pot Cultures. Soil Sci. Soc. Am. Proc. 11:402-406. 
15. Snedecor, G. W. 1956. Statistical Methods. Fifth Edition. The Iowa State College Press, Ames, Iowa.

16. Soubies, L., R. Gadet, and M. Lenain. 1955. Recherches Sur l' Evolution de l' Urée Dans les Sols et Sur Son Utilisation Comme Engrais Azoté. Ann. Agron. 6:1025-1027.

17. Swanson, C. L. W. and H. G. M. Jacobson. 1956. Effect of Soil Hardness and Compaction on Corn Growth. Soil Sci. Soc. Am. Proc. 20:161-167.

18. Wagner, G. H. and G. E. Smith. 195S. Nitrogen Losses from Soils Fertilized with Different Nitrogen Carriers. Soil Sci. 85:125-129.

19. Walkley, A. and T. A. Black. 1934. An Examination of the Degtjareff Method for Determining Soil Organic Matter and a Proposed Modification of the Chromic Acid Titration Method. Soil Sci. 37:29-38. 



